\title{
Teknik Sipil dan Pembangunan Berkelanjutan
}

\author{
Agus Setyo Muntohar ${ }^{\mathrm{a}}$ \\ ${ }^{a}$ Program Studi Teknik Sipil, Fakultas Teknik, Universitas Muhammadiyah Yogyakarta
}

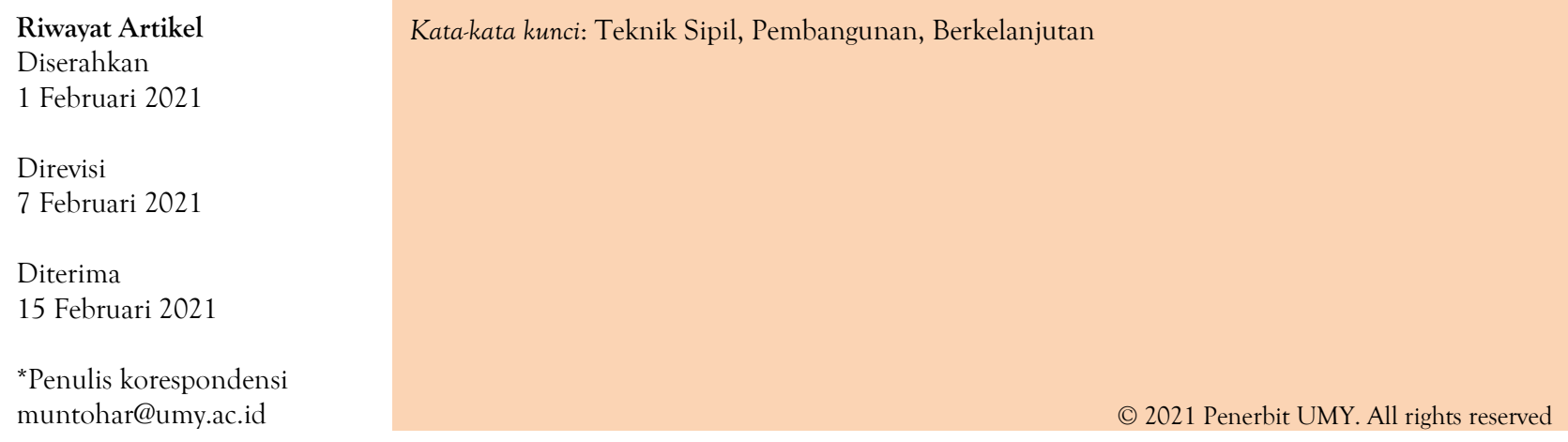

Assalamu'alaikum Wr. Wb.

\section{Teknik Sipil Yang Berkelanjutaan}

Pertumbuhan suatu negara seringkali ditandai dengan pembangunan infrastruktur secara masif. Ilmu Teknik Sipil memiliki peran yang sayang penting dalam pembangunan, mulai dari perencanaan, perancangan, pelaksanaan, dan pengoperasian serta pemeliharaan. Bidang Teknik sipil tidak dapat dipisahkan dengan kehidupan sehari-hari masyarakat. Bangunan pencakar langit yang dapat dilihat di mana-mana, lalu lintas jalan yang berkembang, jembatan yang indah, dan bendungan seperti benteng kokoh, dan terowongan serta bangunan bawah permukaan adalah bagian tak terpisahkan dari kehidupan kita. Setelah memasuki abad baru, dalam lingkungan perkembangan ekonomi yang pesat, kami akan mengantarkan ledakan konstruksi infrastruktur baru. Pengaruh teknik sipil bagi pembangunan ekonomi nasional dan kehidupan masyarakat terlihat jelas. Sebagai topik perhatian paling populer di abad ke-21 di seluruh dunia, pembangunan berkelanjutan memengaruhi semua bidang kehidupan sehari-hari.

Perkembangan pesat struktur ekonomi ibaratkan pedang bermata dua. Keadaan ini memberi kita kekayaan besar tetapi juga menyebabkan kerusakan ekologis lingkungan. Laju ekonomi yang pesat didasarkan pada konsumsi energi skala besar dengan mengorbankan sebagian besar padang rumput dan lahan subur yang telah dibuka, sebagian besar hutan telah ditebang, cadangan minyak, batu bara dan sumber daya alam lainnya yang terbatas ditambang, dan sebagainya. pada, memicu erosi tanah di lembah sungai yang besar, dan hilangnya spesies langka, anomali cuaca buruk dan polusi udara, kekurangan sumber daya mineral dan serangkaian masalah serius.

Tren global pembangunan berkelanjutan, Teknik Sipil harus menghilangkan atau mengurangi masalah lingkungan yang mungkin timbul dalam proyek, seperti pengurangan sumber daya air, penurunan kualitas air, penurunan tanah, erosi tanah, tanah longsor, pencairan bangunan pemukiman, retak . dan banyak bencana lainnya, mulai dari konstruksi ekonomi 
skala besar, sehingga pembangunan tersebut dapat memberikan manfaat bagi umat manusia dan membuat lingkungan hidup mendapatkan pembangunan dan perbaikan yang berkelanjutan. Oleh karena itu, pembangunan berkelanjutan Teknik Sipil menjadi hal yang sangat layak untuk didiskusikan dan dipelajari.

\section{Peran Riset Teknik Sipil}

Dengan senang hati kami mempersembahkan edisi perdana "Buletin Teknik Sipil" (BCE). Jurnal 6 bulanan ini didukung oleh Universitas Muhammadiyah Yogyakarta. BCE menerima artikel berupa artikel orisinal, desain teknis, artikel review, review buku, dan diskusi. Makalah terpilih di BCE didedikasikan untuk perkembangan teknologi di bidang teknik sipil, untuk mencapai solusi berkelanjutan dan konstruksi ramah lingkungan. Ini dimaksudkan sebagai forum internasional untuk berbagi dan membahas hal-hal yang menjadi kepentingan utama, termasuk perkembangan baru dalam peraturan perdata. Volume pengukuhan meliputi 8 artikel yang terdiri dari 4 artikel asli dan 4 desain teknis.

Artikel riset memberikan topik yang berkaitan dengan inovasi dalam teknik sipil dan bagaimana kinerjanya. Farhan dkk. menemukan bahan pengganti semen alternatif untuk peredam getaran, yaitu serbuk karet ban. Hasil penelitian membuktikan rasio pengurangan gaya redaman sesuai dengan konsentrasi serbuk karet ban. Penelitian ini berkontribusi pada pengembangan bahan konstruksi ramah lingkungan. Emil dan Fatimah memodifikasi struktur perkerasan jalan dengan campuran bahan kimia yaitu Plastocrete dan Sikament-NN. Plastocrete dapat mengatur waktu curing untuk beton, sedangkan Sikament-NN dapat meningkatkan kuat tekan awal. Penelitian ini menggunakan software ABAQUS untuk menganalisis kinerja karakteristik perkerasan jalan. Kharoza dkk. menyelidiki perilaku tanah ekspansif akibat penerapan kolom SiCC. Kolom SiCC merupakan salah satu teknologi stabilisasi tanah. Dalam makalah ini, Kharoza dkk memfokuskan pada kekuatan geser tanah di sekitar kolom SiCC daripada penerapan kolom SiCC. Artikel Maulana dan Syarif prihatin dengan gagalnya permukiman akibat aliran debris lahar di daerah vulkanik. Ini memprediksi ketahanan struktur rumah yang terkena gaya hidrostatik dianalisis dengan cara simulasi numerik.

Artikel lainnya diklasifikasikan dalam desain teknis. Gentur dan Harsanto menganalisis stabilitas bendung Kamijoro terhadap pipping, sliding, dan fall. Artikel Heri dan Wilana berfokus pada identifikasi keselamatan dan manajemen risiko. Beberapa potensi risiko yang mungkin terjadi pada konstruksi gedung bertingkat diidentifikasi untuk mencapai keberhasilan proyek konstruksi. Wulandari dan Muchlisin mengevaluasi kinerja simpang bersinyal menggunakan PTV VISSIM. Penelitian ini memberikan rekomendasi kepada pengelola transportasi berdasarkan hasil simulasi. Rahmawati dkk. Perancangan struktur perkerasan jalan menggunakan dua metode yang berbeda yaitu metode Austroads dan metode Analisis Komponen. Untuk mengetahui performansi struktur perkerasan jalan, kedua metode tersebut dievaluasi menggunakan program Kenpave.

Wassalamu'alaikum Wr. Wb.

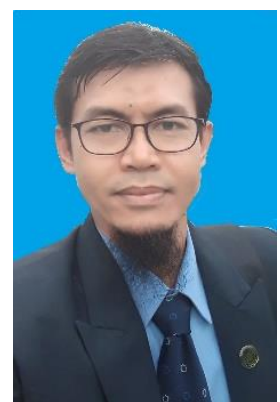

Prof. Agus Setyo Muntohar, Ph.D.

Ketua Dewan Penyunting 